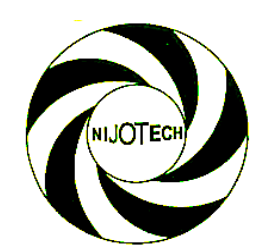

Nigerian Journal of Technology (NIJOTECH)

Vol. 38, No. 2, April 2019, pp. $\mathbf{5 2 6}$ - $\mathbf{5 3 1}$

Copyright@ Faculty of Engineering, University of Nigeria, Nsukka,

Print ISSN: 0331-8443, Electronic ISSN: 2467-8821 www.nijotech.com

http://dx.doi.org/10.4314/njt.v38i2.32

\title{
GROUNDWATER QUALITY PARAMETERS-CORRELATION AND MICROBIAL ANALYSIS
}

\author{
H. I. Owamah* \\ Dept of Civil Engineering, Delta State University, PMB1, Abraka, Oleh Campus, Delta State, Nigeria \\ E-mail addresses: hiowamah@delsu.edu.ng
}

\begin{abstract}
This report gives the correlation and microbial analyses of groundwater, in a rural community, in the South-South of Nigeria for wet and dry season monitoring. Sampling of borehole (BH) and hand-dug well (HDW) water samples was done for eight (8) consecutive months, beginning from May 012016 to January 31, 2017; to cover for wet and dry seasons. In line with standard methods of APHA (2012), over thirty (30) water quality properties were measured and correlated. Results of the correlation analysis showed that the prominent mineral groups responsible for total dissolved solids (TDS) and electrical conductivity (EC) in the groundwater are Mg-Ca (0.98), Ca-Fe (-0.98), $\mathrm{Na}-\mathrm{K}(0.97)$ and $\mathrm{Na}-\mathrm{Mg}(0.96)$ groups and hence, control the chemical properties of the study area groundwater. The correlation analysis also showed that while $\mathrm{Cl}^{\prime}$ and $\mathrm{SO}_{4}{ }^{2-}$ did not exhibit strong preferential affinity for any of the cations, $\mathrm{NO}_{3}^{-}$was perfectly correlated with $\mathrm{Mg}(-0.91)$ and $\mathrm{Cd}$ (0.98), and very strongly with Ca (-0.85) and Ba (0.84). The microbial analysis result revealed that BHs were cleaner sources of potable water in the community, compared with hand-dug wells.
\end{abstract}

Keywords: Groundwater, monitoring, quality parameters, microbial and correlation

\section{INTRODUCTION}

The main source of drinking water in rural areas is groundwater. This is often abstracted through boreholes, hand-pump wells, and sometimes springs [1]. The contamination of these waters pose serious threat to the health of the rural dwellers as they are consumed without any form of treatment [2]. The quality of groundwater could be affected by both natural and anthropogenic activities like geochemical reactions, saline water intrusion, agricultural activities, urbanization, improper waste disposal and others [3]. Environmental monitoring of groundwater quality on regular basis, especially in areas with high risk of contamination is therefore necessary for the protection of public health in developing countries. According to Jones, et al [4], strategies for the monitoring of groundwater are aimed at establishing the current status and evaluation of environmental parameter trends. These help to determine the risks contaminated groundwater could pose to the environment and human health.
Furthermore, because the problem of water is heterogeneous in nature and varies from locality to locality, region to region, monitoring and investigation ought to be local [5]. Recently, countries in Sub-Saharan Africa were noted to have made impressive achievements in the provision of improved water to their citizens as $43 \%$ of their population, reportedly, have gained access to potable water sources. This is however, through private boreholes (groundwater) that are usually not tested and monitored [6]. Nigeria is a prominent country in the Sub-Saharan Africa and has the largest population of over 190 million people [16]. The country, at the moment, still has huge challenges in the area of provision of improved drinking water to her citizens given the near complete absence of pipeborne water scheme [2]. This has now made the majority of Nigerians in both urban and rural communities rely largely on groundwater for drinking and other domestic purposes [7]. Again, Nigeria in the recent last two decades experienced a geometric increase in the number of privately owned boreholes.

Author, tel: $+234-803-570-5814$ 
These boreholes, especially those in rural communities, are seldom monitored for quality assurance [7] and are in some places not adequate to satisfy the growing population. The latter has resulted in the use of unprotected and unsafe water sources like shallow wells by rural dwellers [8]. Given all of the above, this research aimed to investigate the quality of groundwater in Emevor community in order to create the necessary drinking water quality consciousness in the community and facilitate the provision pipe-borne water scheme in the study area.

\section{MATERIALS AND METHODS}

\subsection{Description of Area of Study}

Emevor community is located in the Isoko North Local Government Area (INLGA) of Delta State, Nigeria. The establishment of one of the study centers of the National Open University of Nigeria, has recently led to increase in population and pressure on essential natural resources like water. From Figure 1, the coordinates of the INLGA are $5^{0}-20^{\prime}$ and $5^{0}-37^{\prime}$ north latitudes, and $6^{0}-12^{\prime}$ and $6^{0}-13^{\prime}$ east longitudes. The geographical location of the area shows that Emevor community is surrounded by Iyede, Otor-Owhe, Agbarah, Orogun and Otor-otie communities.

The INLGA experiences two major seasons each year; the wet season, beginning in April to terminate in September and the dry season, which commences in late October and terminates in March ending [7]. Though the main vegetation is rainforest, some areas are of swamp forest [9]. The INLGA with an estimated population of approximately one hundred and forty thousand persons in 2006 is one the major crude oil producing Local Government Areas in Nigeria [7].

\subsection{Water Quality Sampling and Analysis}

Water samples were taken in triplicates from randomly selected bore-holes and hand- dug wells in the representative locations, following the prescribed guidelines in APHA [10]. Figure 1 is the map of the INLGA showing the study area. The sample collection began on the first day of June 2016 and ended on the last day of January, 2017 using new PET bottles that were properly rinsed. In order to avoid contamination and degradation of samples, extra care was observed in the course of sampling, in-situ analyses and sample preservation. Samples for physicochemical and microbial analyses were put in an ice-containing cooler box and thereafter taken to the laboratory for analyses. Samples for metals determination were preserved with the use of few drops of concentrated hydrogen trioxo -nitrate $(\mathrm{V})$ acid. Fifteen samples of borehole and hand-dug water samples were obtained on monthly basis to give a total of 120 raw water samples. The water samples were kept in a refrigerator at $4^{\circ} \mathrm{C}$ prior to analyses. Experimental data was analyzed using Microsoft Excel, 2010 version to generate the means, standard deviations and seasonal differences for wet and dry seasons. Analysis of Variance (ANOVA) at 5\% significant level was also used for further statistical analysis of experimental data.

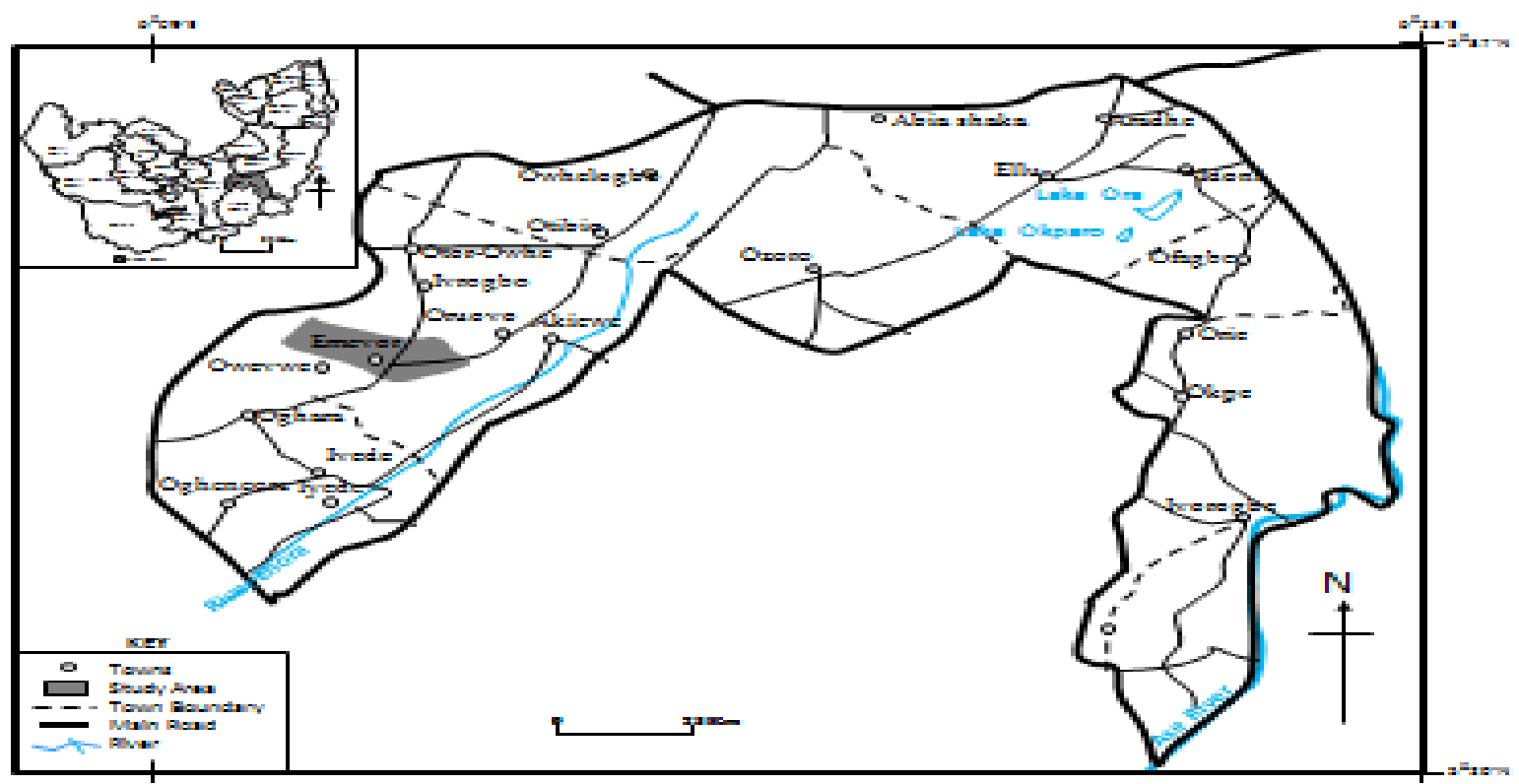

Fig. 1: Map of Isoko North showing Study Area (Source: Ministry of Lands, Surveys and urban Development, 2013) 


\subsection{Analytical Procedures}

Samples were analyzed for thirty three (33) physicochemical parameters using standard methods. At the site, turbidity was measured using portable turbidimeter. $\mathrm{pH}$, TDS and EC were also measured using portable multimeter (Hanna Instruments, $\mathrm{HI}$ 9812). In line with Owamah, et al [7], anions were measured with a UV spectrophotometer. The concentrations of metals were analyzed with atomic absorption spectrophotometer, following the stipulations in APHA [10]. Membrane filtration technique was adopted for the determination of fecal coliform (FC) bacteria following standard guidelines as documented in APHA [10]. The standard plate count procedure was used for the determination of the visible bacterial colonies expressed as CFU/100 mL. The statistics of experimental data obtained were compared with the WHO and SON standards for drinking water.

\section{RESULTS AND DISCUSSION}

\subsection{Correlation Analysis}

Table 1 shows the outcome of the correlation analysis of the main physicochemical parameters obtained for Emevor community groundwater.

\subsection{Discussion}

\subsubsection{Microbial Contamination}

While an average $E$. coli value of $228.44 \mathrm{CFU} / 100 \mathrm{~mL}$ was obtained from hand-dug well (HDW) water samples, bore-hole $(\mathrm{BH})$ water samples had a lower average value of $180.56 \mathrm{CFU} / 100 \mathrm{~m} \mathrm{~L}$. Furthermore, the average total coliform count (TCC) in the HDW water samples was $2.65 \mathrm{CFU} / 100 \mathrm{~mL}$ and was higher than the average value of $0.94 \mathrm{CFU} / 100 \mathrm{~m} \mathrm{~L}$ gotten from the $\mathrm{BH}$ water samples. This indicated that the HDWs were more contaminated sources of drinking water in the study area. Higher TCC values were also obtained in the rainy season compared with the dry season. For wet and dry seasons, the average values obtained, were $0.38 \mathrm{CFU} / 100 \mathrm{~mL}$ and 3.30 $\mathrm{CFU} / 100 \mathrm{~mL}$, respectively with a range of 0.00 $\mathrm{CFU} / 100 \mathrm{~mL}-1.80 \mathrm{CFU} / 100 \mathrm{~mL}$ (wet season) and 1.00 CFU/100 mL -5.76 CFU/100 mL (dry season). The maximum TCC (5.76 CFU/100 mL) was obtained from an HDW, in the month of January (dry season). These values of TCC obtained showed that the groundwater is bacterial contaminated as the values violate the WHO prescription of OCFU/100 mL. Simple household chemical treatment or boiling is advised to prevent future outbreak of water-related diseases. Enterobacter aerogenes and E. coli. found in the samples of both wells are usually found in grains, plant surfaces, feces and the intestines of animals and humans [2]. The presence of these isolated organisms in the water samples signifies that the groundwater had contact with fecal matter of humans and or animals [15]. Similar finding had been obtained by Sojobi [8] for Omu-Aran, groundwater in Kwara State. Olufemi and Oluwole [11] had earlier reported that $E$. coli and $E$. aerogenes contributed significantly to Ibadan cholera outbreak. At $\mathrm{P}<0.05$, ANOVA indicated that no significant difference existed in the physical and chemical properties of the BHs and HDWs. No significant difference was obtained for the parameters across the seasons at $P<0.05$. Detailed discussions on the physicochemical parameters have obtained and documented.

\subsubsection{Correlation Analysis of Parameters Tested} In line with Sojobi [8] the correlation categories adopted for this research are: perfect $\left(R^{2}=1\right)$, very strong $\left( \pm 0.9 \leq R^{2} \leq 1\right)$, strong $\left( \pm 0.7 \leq R^{2}< \pm 0.9\right)$, moderate $\left( \pm 0.5 \leq R^{2}< \pm 0.9\right)$, and poor $\left(R^{2}< \pm 0.5\right)$. Table 1 showed the result of the correlation analysis of parameters tested in this study. From Table 1, the major cations contributing to TDS were $\mathrm{Ca}(0.99), \mathrm{Mg}$ (0.99), Ba (0.99), Fe (-0.98), $\mathrm{Na}(0.95)$, and $\mathrm{K}(0.85)$. TDS was also, very strongly correlated with $\mathrm{BOD}_{5}$ $(0.89), \mathrm{NO}_{3}{ }^{-}(-0.84)$, TSS $(0.86)$ and perfectly with DO (0.97). These results were in line with the reports of Sojobi [8] and Viswanath et al. [17] in which calcium was said to be the most influential parameter for the prediction of total dissolved solids in groundwater. Results of the correlation analysis also showed that the prominent mineral groups responsible for total dissolved solids (TDS) and EC in the groundwater were; Mg-Ca (0.98), Ca-Fe group (-0.98), Na-K (0.97) and $\mathrm{Na}-\mathrm{Mg}(0.96)$ groups. These could therefore be described as being in control of the chemical properties of study area groundwater.

$\mathrm{NO}_{3}{ }^{-}$was associated with $\mathrm{Mg}$-Ca group with correlation coefficients [-0.91- $(0.85)]$ respectively. There was no observed correlation for magnesium and calcium with $\mathrm{Cl}^{-}$. In line with the report of Skrzypek, et al. [12], $\mathrm{Mg}^{2+}$ and $\mathrm{Ca}^{2+}$ could have associated themselves with other anions in the groundwater. $\mathrm{Mg}$ and $\mathrm{Ca}$ had strong correlation coefficient of (0.98), indicative of possible high mutual dependence and related anthropogenic sources [13]. 
Table 1: Correlation Analysis

\begin{tabular}{|c|c|c|c|c|c|c|c|c|c|c|c|c|c|c|c|c|c|}
\hline & $p H$ & $E C(\mu S / c m)$ & TDS (mg/l) & $\overline{D O}(\mathrm{mg} / \mathrm{l})$ & $B O D 5(m g / l)$ & NO3-N (mg/l) & $\mathrm{Cl}(\mathrm{mg} / \mathrm{l})$ & SO4 (mg/l) & $\mathrm{Na}$ (ppm) & $K(p p m)$ & $M g(p p m)$ & $\mathrm{Ca}(p p m)$ & $C d(p p m)$ & Zn (ppm) & Cu (ppm) & $F e(p p m)$ & $\mathrm{Ba}(\mathrm{ppm})$ \\
\hline $\mathrm{pH}$ & 1 & & & & & & & & & & & & & & & & \\
\hline$E C(\mu S / c m)$ & -0.98727 & 1 & & & & & & & & & & & & & & & \\
\hline TDS (mg/l) & 0.01659 & -0.03615 & 1 & & & & & & & & & & & & & & \\
\hline $\mathrm{DO}(\mathrm{mg} / \mathrm{l})$ & 0.157133 & -0.14329 & 0.970352 & 1 & & & & & & & & & & & & & \\
\hline BOD5 (mg/l) & 0.46156 & -0.45305 & 0.885556 & 0.947203 & 1 & & & & & & & & & & & & \\
\hline NO3-N (mg/l) & -0.48261 & 0.534444 & -0.84341 & -0.83296 & -0.92308 & 1 & & & & & & & & & & & \\
\hline $\mathrm{TH}(\mathrm{mg} / \mathrm{l})$ & 0.275498 & -0.23564 & 0.902555 & 0.979827 & 0.959135 & -0.7933 & & & & & & & & & & & \\
\hline $\mathrm{Cl}(\mathrm{mg} / \mathrm{l})$ & -0.01473 & 0.170609 & -0.31349 & -0.11918 & -0.16159 & 0.518284 & 1 & & & & & & & & & & \\
\hline SO4 (mg/l) & 0.95637 & -0.89931 & -0.09447 & 0.096561 & 0.378796 & -0.29829 & 0.277353 & 1 & & & & & & & & & \\
\hline $\mathrm{Na}$ (ppm) & -0.15254 & 0.173985 & 0.948787 & 0.94939 & 0.798848 & -0.65111 & -0.04197 & -0.17856 & 1 & & & & & & & & \\
\hline $\mathrm{K}(\mathrm{ppm})$ & -0.33795 & 0.380018 & 0.845982 & 0.849846 & 0.642559 & -0.44332 & 0.118425 & -0.30886 & 0.968975 & 1 & & & & & & & \\
\hline $\mathrm{Mg}(\mathrm{ppm})$ & 0.137358 & -0.16578 & 0.99037 & 0.964844 & 0.922548 & -0.90967 & -0.3756 & 0.004086 & 0.901283 & 0.768277 & 1 & & & & & & \\
\hline $\mathrm{Ca}(\mathrm{ppm})$ & 0.097394 & -0.09887 & 0.990986 & 0.993974 & 0.927278 & -0.84572 & -0.21009 & 0.012823 & 0.955143 & 0.852599 & 0.984044 & 1 & & & & & \\
\hline $\mathrm{Cd}(\mathrm{ppm})$ & -0.59691 & 0.660887 & -0.72482 & -0.71442 & -0.85721 & 0.981081 & 0.57837 & -0.39351 & -0.49195 & -0.26151 & -0.81311 & -0.72681 & 1 & & & & \\
\hline Zn (ppm) & 0.564585 & -0.46039 & 0.485413 & 0.681859 & 0.764027 & -0.49318 & 0.482718 & 0.669796 & 0.547126 & 0.484718 & 0.502634 & 0.598065 & -0.43207 & 1 & & & \\
\hline $\mathrm{Cu}(\mathrm{ppm})$ & 0.587857 & -0.48885 & 0.502416 & 0.695198 & 0.785228 & -0.52686 & 0.446195 & 0.681394 & 0.550667 & 0.477944 & 0.524451 & 0.613294 & -0.46971 & 0.999059 & 1 & & \\
\hline $\mathrm{Fe}(\mathrm{ppm})$ & 0.098674 & -0.10632 & -0.97712 & -0.96707 & -0.83661 & 0.723238 & 0.135246 & 0.153969 & -0.99427 & -0.93876 & -0.94175 & -0.97811 & 0.575877 & -0.53104 & -0.53917 & 1 & \\
\hline Ba (ppm) & 0.113328 & -0.11119 & 0.987045 & 0.996547 & 0.933612 & -0.84435 & -0.18897 & 0.034232 & 0.954351 & 0.85208 & 0.980655 & 0.999642 & -0.72563 & 0.61928 & 0.634122 & -0.9762 & 1 \\
\hline
\end{tabular}


$\mathrm{NO}_{3}{ }^{-}$has perfect correlation coefficients with $\mathrm{Cd}(0.98)$ and $\mathrm{Mg}(-0.91)$ and a very strong one with $\mathrm{Ba}$ (0.84). This is also indicative of related anthropogenic origins like domestic wastewater for the metals. Table 1 shows that there were ionic exchange and affinity reactions in the aquifer system of the groundwater [8]. While $\mathrm{Cl}^{-}$and $\mathrm{SO}_{4}{ }^{2-}$ were found not to exhibit strong preferential affinity for any of the cations, $\mathrm{NO}_{3}{ }^{-}$was perfectly correlated with $\mathrm{Mg}(-0.91)$ and $\mathrm{Cd}$ (0.98), and very strongly correlated with $\mathrm{Ca}(-0.85)$ and $\mathrm{Ba}$ (0.84).

An aquifer that is $\mathrm{Mg}$ rich allows the dissolution of $\mathrm{Mg}$ into it. However, the main anions in the aquifer minerals still do not prefer $\mathrm{Mg}$ even in the dissolved form [8]. This could therefore be the reason for the relatively high concentration of $\mathrm{Mg}$ in both the handdug well and borehole water samples. This postulation is supported by findings of Sojobi [8] and Akri [14] that the chemistry of groundwater is majorly influenced by the dissolution of halite and anthropogenic activities. $\mathrm{pH}$ and EC were found to be respectively, perfectly $(0.96)$ and very strongly $(-0.90)$ correlated with $\mathrm{SO}_{4}{ }^{2-}$. EC was found to be poorly correlated with $\mathrm{DO}, \mathrm{Fe}, \mathrm{NO}_{3}{ }^{-}$, $\mathrm{Ca}$ and $\mathrm{BOD}_{5}$ indicating that these parameters may not be applicable for the prediction of EC in the groundwater of study area. This is however, contrary to the findings of Sojobi [8] for Omu-Aran groundwater in Kwara State, Nigeria.

\section{CONCLUSION}

The study investigated the correlation analysis of the physicochemical parameters of Emevor groundwater and the microbial load. Results of the correlation analysis showed that the prominent mineral groups responsible for TDS and EC in the groundwater were $\mathrm{Mg}-\mathrm{Ca}$, $\mathrm{Ca}-\mathrm{Fe}, \mathrm{Na}-\mathrm{K}$ and $\mathrm{Na}-\mathrm{Mg}$ groups and hence, control the chemical properties of the groundwater. The correlation analysis showed that while $\mathrm{Cl}^{-}$and $\mathrm{SO}_{4}{ }^{2-}$ were found not to exhibit strong preferential affinity for any of the cations and anions, $\mathrm{NO}_{3}{ }^{-}$was perfectly correlated with $\mathrm{Mg}$ (negatively) and $\mathrm{Cd}$ (positively), and very strongly correlated with $\mathrm{Ca}$ (negatively) and Ba (positively). Finding from the study further showed that the groundwater had coliform bacteria. The coliform organisms were mainly detected, in the hand-dug wells. The coliform bacteria contamination was attributed to the close proximity of the water wells to pit-latrines and poorly constructed septic tanks. The various open dumps in the community could have also contributed. Besides the need for the provision of clean water sources for the community, putting in place modern sanitary facilities and sensitization programmes are also recommended.

\section{ACKNOWLEDGEMENT}

I appreciate the huge assistance of the Academic Research and Entrepreneurship Development (A-RED) Initiative, Asaba, Nigeria to this research.

\section{REFERENCES}

[1] Dwairo, B., Hoko, Z., Love, D., \& Guzha, E. (2006). Assessment of the impacts of pit latrines on groundwater quality in rural areas: a case study from Marondera district of Zimbabwe. Physics and Chemistry of the Earth, 31, 779-788.

[2] Dahunsi, S. O., Owamah, H. I., Ayandiran, T. A., Oranusi, U. S., \& (2014). Drinking water quality and public health of selected communities in South Western Nigeria. Water Quality, Exposure and Health, 6, 143-153.

[3] Akhtar, M. M., Tang, Z., \& Mohamadi, B. (2014). Contamination potential assessment of potable groundwater in Lahore. Polish Journal of Environmental Studies, 23(6), 1095-1916.

[4] Jones, W.R., Spence, M.J., Bowman, A.W., Evers, L., Molinari, D.A., 2014. A software tool for the spatiotemporal analysis and reporting of groundwater monitoring data. Environ. Model. Software 55, 242-249.

[5] Biswas, A. K., \& Tortajada, C. (2010). Future water governance: problems and perspectives. International Journal of Water Resources, 26(2), 129-139.

[6] WHO/UNICEF, 2015. World Health Organization (WHO) and United Nations Children's Fund (UNECEF), Progress on Sanitation And Drinking Water e 2015 Update and MDG Assessment, WHO, Switzerland, 2015. Available. http://www.

[7] Owamah, I.H., Asiagwu, A.K.,. Egboh, S.H.O \& Phil-Usiayo, S. (2013). Drinking water quality at Isoko North communities of the Niger Delta Region, Nigeria Toxicological \& Environmental Chemistry, Vol. 95, No. 7, 1116-1128.

[8] Sojobi, S.O (2016). Evaluation of groundwater quality in a rural community in North Central of Nigeria. Environ Monit Assess (2016) 188:192.

[9] Agbogidi, O.M., P.G. Eruotor, S.O. Akparobi and G.U Nnaji, 2007. Heavy metal contents of maize (Zea mays L.) grown in soil contaminated with crude oil. International Journal of Botany 3(4):385-389.

unicef.org/publications/index_82419.htmL. 
[10] APHA 2012. "Standard Methods for Examination of Water and Waste-water"; 22nd Edition, Washington DC: American Public Health Association.

[11] Olufemi, F., \& Oluwole, M. F. (2012). Microbiological examination of sachet water due to a cholera outbreak in Ibadan, Nigeria. Open Journal of Medical Microbiology, 2, 115-120.

[12] Skrzypek, G., Dogramaci, S., \& Grierson, P. F. (2013). Geochemical and hydrological processes controlling groundwater salinity of a large inland wetland of northwest Australia. Chemical Geology, 357, 164-177.

[13] Devic, G., Djordjevic, D., \& Sakan, S. (2014). Natural and anthropogenic factors affecting the groundwater in Serbia. Science of the Total Environment, 468-46, 933-942.
[14] Akri, B. (2015). Hydrochemical processes regulating groundwater quality in the coastal plain of Al Musanaah, Sultanate of Oman. Journal of African Earth Sciences, 106, 87-98.

[15] Mackie, R. I., Koike, S., Krapac, I., Chee-Sanford, J.,Maxwell, S., \& Aminov, R. I. (2006). Tetracycline residues and tetracycline resistance genes in groundwater impacted by swine production facilities. Animal Biotechnology, 17, 157-176.

[16] National Population Commission of Nigeria (NPC). http://www.informationng.com/tag/nationalpopulation- commission. Accessed on the $25^{\text {th }}$ of December, 2018 at 14.22 Nigerian time.

[17] Viswanath, N. C., Kumar, P. G. D., \& Ammad, K. K. (2015). Statistical analysis of quality of water in various water shed for Kozhikode City, Kerala, India. Aquatic Procedia, 4, 1078-1085. 